\title{
Analysis on The Influencing Factors of The Average Service Life of Urban Housing in China
}

\author{
Tingting $\mathrm{Gu}$ \\ School of Management, Xian University of Architecture and Technology, Xian 710055, China \\ 1075527886@qq.com
}

Keyword: The average service life, Questionnaire survey, Principal components analysis

\begin{abstract}
At present, China's residential average life is less than 30 years, far below the standard design life of 50 years, and the residential life in developed countries generally up to 80 years. Our residential life is so short that gives our country's construction and economic development a lot of negative factors. This paper focuses on the average service life of existing housing, using questionnaires survey and principal component analysis analyzes the factors that affect the average life.
\end{abstract}

\section{Introduction}

In recent years, according to the relevant laws of our country, the endurance life of the high-rise building and the major structure of the important buildings is 100 years, the general building is 50 100 years. However, in real life, there is a considerable gap between the actual life of many buildings and the legal requirements. The average service life of the existing residential buildings is only 30 years [1]. In 2013, the housing construction area of real estate development enterprises has reached 6656000000 square meters, but the process of urbanization Chinese will also continue to maintain rapid development. At the same time, a large number of urban construction in the use of less than 50 years will be removed. According to the relevant data statistics, China's housing has been dismantled 120000000 square meters in 2002, a total of about 161000000 square meters of in 2003, the use of these residential life is far from reaching the design life [2]. The construction of short-lived problems caused by the model of this large-scale demolition and construction has attracted more and more attention, the research on the service life of buildings is also increasing. According to this phenomenon, this paper intends to study the factors affecting the average service life of existing residential buildings in China by questionnaire survey method and principal component analysis.

\section{Research methods}

\subsection{Research hypothesis}

Because the development of the existing residential area is a wide range, there are so many relevant variables that impact the existing residential average life, the link between the variables is very complex. In a different environment and perspective, the influence of variables on the average service life will be different. Therefore, it is necessary to put forward the research hypothesis research.

The research hypothesis is the hypothesis that the characteristics of the investigation object and the relation between the phenomenon and the related phenomena, it is the attempt to solve the problem.

Hypothesis one: the development of the average service life of residential is affected by 37 variables, and in this paper is being exhausted. Because in the process of the study we can't guarantee the integrity and the representative of the literature, and the previous research environment and the present stage may be different, so the research will have an impact [3].

Hypothesis two: these 37 variables can be integrated into a number of factors, including a number of key factors play a decisive role. 
F.H.Mustapha research found that, in the field of management, the impact of many factors can be integrated into a number of factors, and these factors are not equally important, only a few of them play a key role, including professional ability and working conditions is one of the key factors [4]. And so on, we believe that there are several key factors in the development of the existing residential average service life.

\subsection{Preparation of questionnaire}

On the basis of the 37 variables listed, by referring to a variety of documents, according to the classification of the 5 elements of the problem, the variables will be quantified. Here we use Liken self rating scale method of 5, from the "not important" to "very important" are recorded as 1 points, 2 points, 3 points, 4 points, 5 points, higher scores indicate that the research described the more close to the actual situation [5]. The value of this method is to distinguish the difference between the object and the intensity of the object in a certain logical order. However, this method is lack of a complete set of axioms and theorems, In the course of the study, we should pay attention to the reliability and validity of the measurement.

\section{Questionnaire survey method}

The questionnaire survey method is applicable to a wide range of research issues. Adopting questionnaire survey method, the questionnaire survey method can reflect the user's problems in a comprehensive and timely manner, provide more accurate information and can get the background information of the survey object and the original data that is not easy to get [6]. The investigation lasted from late April 2015 to late May 2015. Due to the limitation of time, manpower and capital, the questionnaire was sent to the Gansu Province for facilitate the research, personally sent to the survey units and individuals, a total of 120 copies. Questionnaires are as follows:

\section{The Influence Factors of Average Service Life of Urban Housing in China.}

1. Basic data of the respondents

(1) Gender: A. Male5 ( ) B. Female5 ( )

(2) Age: A. Under the age of 25( ) B. 25 35 years old ( ) C.36 44 years old ( ) D. Over 45 years old ( )

(3) Education: A. College Specialty ( ) B. University degree ( ) C. Graduate student ( ) D. Other ( )

(4) Employment unit: A. Government Departments ( ) B. Real Estate Company ( ) C. Construction unit ( ) D. Government-affiliated institutions ( ) E. Other ( )

(5) Cumulative time: A.1 2 ( ) B.2 5 ( ) C.5 10 ( ) D. Over 10 years ( )

2. Overall survey (Please think of the correct option before you draw "tick")

(1) Do you know the average service life of the house?

A. Very understanding ( ) B. Comparative understanding ( ) C. General understanding ( ) D. Not quite understand ( ) E. Completely without understanding ( )

(2) Are you satisfied with the status of the average service life of urban residential buildings in China?

A. Not satisfied ( ) B. Less satisfactory ( ) C. General ( ) D. Comparatively satisfied ( ) E. Very satisfied ( )

(3) In the process of the development of urban residential average service life in our country, do you think the cooperation of various departments is high?

A. Very high ( ) B. Relatively high ( ) C. General ( ) D. Less high ( ) E. Very not high ( )

(4) Please rank the following factors influencing the average service life of urban residential buildings in China

A. Policy specification B. Market environment C. Management organization D. Economic cost E. Technical standard F. Other

3. Key factors questionnaire

Please rate the following factors—— the higher the probability, the higher the score. a " $\sqrt{ }$ " tick below what you think that is the correct answer.

(1: No effect 2: A bit of influence 3: General effect4: Impact 5: Great influence) 


\begin{tabular}{|c|c|c|c|c|c|c|c|}
\hline \multicolumn{2}{|c|}{ Factor Number } & \multirow[t]{2}{*}{ Influence Variable } & \multicolumn{5}{|c|}{$\begin{array}{l}\text { The Possibility } \\
\text { (Score) }\end{array}$} \\
\hline & & & 1 & 2 & 3 & 4 & 5 \\
\hline City & 1 & $\begin{array}{l}\text { Poor planning quality, predictability, coordination is } \\
\text { not strong }\end{array}$ & & & & & \\
\hline Planning & 2 & The current management system fragmentation & & & & & \\
\hline and & 3 & Official authorization results in planning dummy & & & & & \\
\hline $\begin{array}{l}\text { Government } \\
\text { Decision-ma }\end{array}$ & 4 & $\begin{array}{l}\text { The government moved to engage in big demolition } \\
\text { and construction }\end{array}$ & & & & & \\
\hline king Factors & 5 & $\begin{array}{c}\text { The national level is not yet perfect system of laws } \\
\text { or administrative regulations }\end{array}$ & & & & & \\
\hline \multirow{19}{*}{$\begin{array}{c}\text { Residential } \\
\text { Technical } \\
\text { Design } \\
\text { Factors }\end{array}$} & 6 & The unit area is too large or too small & & & & & \\
\hline & 7 & Lack of functional design & & & & & \\
\hline & 8 & Sound insulation is not good & & & & & \\
\hline & 9 & Lack of equipment and facilities & & & & & \\
\hline & 10 & Lack of Accessibility equipment & & & & & \\
\hline & 11 & Improper layout of residential space & & & & & \\
\hline & 12 & Insufficient ventilation and lighting & & & & & \\
\hline & 13 & Not energy saving measures & & & & & \\
\hline & 14 & $\begin{array}{c}\text { Not enough residential building structure and } \\
\text { foundation }\end{array}$ & & & & & \\
\hline & 15 & No fire prevention measures & & & & & \\
\hline & 16 & Not enough equipment safety problem & & & & & \\
\hline & 17 & Main body structure durability & & & & & \\
\hline & 18 & Poor retaining structure & & & & & \\
\hline & 19 & Poor waterproof performance & & & & & \\
\hline & 20 & Poor equipment durability & & & & & \\
\hline & 21 & Inadequate parts durability & & & & & \\
\hline & 22 & Residential Land Limited & & & & & \\
\hline & 23 & Limited planning conditions & & & & & \\
\hline & 24 & Residential surrounding environment is bad & & & & & \\
\hline Residential & 25 & Inadequate facilities & & & & & \\
\hline Market and & 26 & Dangerous construction facilities & & & & & \\
\hline Environmen & 27 & District internal functional partition is not clear & & & & & \\
\hline \multirow[t]{4}{*}{ t Factors } & 28 & The volume control is not proper & & & & & \\
\hline & 29 & Landscape and green space planning is unreasonable & & & & & \\
\hline & 30 & Rapid population growth & & & & & \\
\hline & 31 & Family structure changes too fast & & & & & \\
\hline The & 32 & The life cycle cost is too high & & & & & \\
\hline Economic & 33 & Land value is too high & & & & & \\
\hline Cost Factors & 34 & Traffic inconvenience & & & & & \\
\hline of Residence & 35 & Each stage of construction without interlocking & & & & & \\
\hline \multirow{2}{*}{ Other } & 36 & Natural disaster & & & & & \\
\hline & 37 & Regional & & & & & \\
\hline
\end{tabular}

From the results of the survey, a total of 84 questionnaires were returned. The integrity and authenticity of the questionnaire were examined. If there is a leak out of the questionnaire, the questionnaire is removed. If there are 8 questions in a row to choose the same answer or answer to some of the rules of the questionnaire, as a waste volume processing, not included in the statistical analysis of the results. Finally, a total of 72 valid questionnaires were collected. Because the number of valid questionnaires is larger than the sample size, it can be considered as effective. In this survey, the questionnaire's recovery rate was $70 \%$, the effective rate was $60 \%$. As shown in table 1: 
Table 1 Questionnaire distribution and recovery

\begin{tabular}{ccccc}
\hline Issuing Unit & $\begin{array}{c}\text { Distribution } \\
\text { Number }\end{array}$ & $\begin{array}{c}\text { Recycling } \\
\text { Number }\end{array}$ & $\begin{array}{c}\text { Valid } \\
\text { Questionnaire }\end{array}$ & $\begin{array}{c}\text { Invalid } \\
\text { Questionnaire }\end{array}$ \\
\hline Government & 30 & 16 & 15 & 1 \\
$\begin{array}{c}\text { Departments } \\
\text { Construction Unit }\end{array}$ & 26 & 20 & 17 & 3 \\
Residential & 64 & 48 & 40 & 8 \\
Housing & 120 & 84 & 72 & 12 \\
Total & & & & \\
\hline
\end{tabular}

For the accuracy of the results of the questionnaire, the credibility of the questionnaire is high. In the case of high credibility, the principal component analysis is used to analyze the influence factors of the average service life of urban residential.

\section{Principal components analysis}

There are two ways to determine the principal components: One is determined by the size of the eight values, generally take more than 1 of the value of the characteristics. Two is based on the factor of the cumulative variance contribution rate to determine, The cumulative contribution rate of the general variance reached $70 \% \sim 80 \%[7]$.Using SPSS15.0 to combine data, the total variance explained in table 2 is as follows:

Table 2 Total variance explanation

\begin{tabular}{|c|c|c|c|c|c|c|c|}
\hline \multicolumn{5}{|c|}{ Final Result } & \multicolumn{3}{|c|}{ Final Result } \\
\hline $\begin{array}{c}\text { Compone } \\
\text { nt } \\
\text { Number }\end{array}$ & $\begin{array}{c}\text { Characteris } \\
\text { tic Value }\end{array}$ & $\begin{array}{c}\text { Contributio } \\
\text { n Rate } \%\end{array}$ & $\begin{array}{c}\text { Cumulativ } \\
\mathrm{e} \\
\text { Contributi } \\
\text { on Rate } \%\end{array}$ & $\begin{array}{c}\text { Compone } \\
\text { nt } \\
\text { Number }\end{array}$ & $\begin{array}{c}\text { Characterist } \\
\text { ic Value }\end{array}$ & $\begin{array}{l}\text { Contributi } \\
\text { on Rate } \%\end{array}$ & $\begin{array}{c}\text { Cumulativ } \\
\mathrm{e} \\
\text { Contributi } \\
\text { on Rate \% }\end{array}$ \\
\hline 1 & 13.028 & 19.763 & 19.763 & 9 & 2.218 & 3.201 & 80.797 \\
\hline 2 & 8.501 & 12.616 & 32.379 & 10 & 1.933 & 2.913 & 83.710 \\
\hline 3 & 5.684 & 8.714 & 41.093 & 11 & 1.775 & 2.611 & 86.321 \\
\hline 4 & 4.862 & 7.355 & 48.448 & 12 & 1.502 & 2.238 & 88.559 \\
\hline 5 & 4.301 & 6.461 & 54.909 & & & & \\
\hline 6 & 3.633 & 5.496 & 60.405 & 21 & 0.000 & 0.000 & 100.000 \\
\hline 7 & 3.452 & 5.276 & 65.681 & & .......... & .......... & ............. \\
\hline 8 & 2.318 & 3.388 & 77.596 & 37 & & & 100.000 \\
\hline
\end{tabular}

This study uses the variance of the cumulative contribution rate reached $70 \%$ of the requirements, the extraction of eight principal components. However, because the number of variables is too much, and in order to facilitate analysis of the search key, the eight main components of the first five of the $80 \%$ main components of the first 4 , that is, the threshold value of five principal components. Using the SPSS software, a negative load matrix of $37^{*} 5$ can be obtained in table 3 : 
Table 3 Factor negative load matrix

\begin{tabular}{|c|c|c|c|c|c|c|c|c|c|c|c|}
\hline \multirow{2}{*}{$\begin{array}{c}\text { Variabl } \\
\mathrm{e}\end{array}$} & \multicolumn{5}{|c|}{ Principal component } & \multirow{2}{*}{$\begin{array}{c}\text { Variabl } \\
\text { e }\end{array}$} & \multicolumn{5}{|c|}{ Principal component } \\
\hline & 1 & 2 & 3 & 4 & 5 & & 1 & 2 & 3 & 4 & 5 \\
\hline 1 & 0.099 & $\begin{array}{c}-0.14 \\
3\end{array}$ & 0.196 & 0.168 & $\begin{array}{c}-0.12 \\
6\end{array}$ & 20 & $\begin{array}{c}-0.31 \\
5\end{array}$ & 0.317 & 0.373 & $\begin{array}{c}-0.15 \\
7\end{array}$ & 0.254 \\
\hline 2 & $\begin{array}{c}-0.04 \\
9\end{array}$ & 0.112 & -0.07 & $\begin{array}{c}-0.12 \\
7\end{array}$ & 0.237 & 21 & 0.865 & $\begin{array}{c}-0.11 \\
4\end{array}$ & $\begin{array}{c}-0.09 \\
6\end{array}$ & 0.049 & 0.276 \\
\hline 3 & 0.633 & $\begin{array}{c}-0.21 \\
5\end{array}$ & -0.22 & $\begin{array}{c}-0.17 \\
7\end{array}$ & 0.346 & 22 & $\begin{array}{c}-0.25 \\
1\end{array}$ & 0.336 & 0.118 & 0.621 & 0.237 \\
\hline 4 & $\begin{array}{c}-0.06 \\
7\end{array}$ & $\begin{array}{c}-0.16 \\
7\end{array}$ & 0.743 & -0.04 & $\begin{array}{c}-0.01 \\
4\end{array}$ & 23 & 0.251 & 0.743 & $\begin{array}{c}-0.20 \\
3\end{array}$ & 0.379 & $\begin{array}{c}-0.30 \\
2\end{array}$ \\
\hline 5 & 0.444 & 0.075 & 0.325 & $\begin{array}{c}-0.04 \\
1\end{array}$ & $\begin{array}{c}-0.24 \\
6\end{array}$ & 24 & 0.245 & 0.255 & 0.584 & 0.092 & 0.038 \\
\hline 6 & 0.426 & 0.109 & $\begin{array}{c}-0.46 \\
2\end{array}$ & 0.007 & $\begin{array}{c}-0.01 \\
7\end{array}$ & 25 & $\begin{array}{c}-0.10 \\
2\end{array}$ & $\begin{array}{c}-0.19 \\
5\end{array}$ & 0.113 & 0.403 & 0.098 \\
\hline 7 & 0.122 & 0.794 & 0.145 & 0.055 & 0.021 & 26 & 0.124 & 0.035 & 0.364 & 0.294 & $\begin{array}{c}-0.37 \\
3\end{array}$ \\
\hline 8 & 0.708 & 0.143 & 0.301 & $\begin{array}{c}-0.10 \\
3\end{array}$ & -0.23 & 27 & 0.257 & 0.393 & $\begin{array}{c}-0.20 \\
6\end{array}$ & 0.379 & $\begin{array}{c}-0.31 \\
5\end{array}$ \\
\hline 9 & 0.813 & 0.467 & $\begin{array}{c}-0.20 \\
3\end{array}$ & 0.248 & 0.345 & 28 & 0.575 & 0.105 & $\begin{array}{c}-0.10 \\
7\end{array}$ & 0.095 & $\begin{array}{c}-0.60 \\
7\end{array}$ \\
\hline 10 & 0.233 & 0.246 & 0.584 & 0.092 & 0.032 & 29 & $\begin{array}{c}-0.00 \\
4\end{array}$ & 0.638 & 0.109 & 0.203 & $\begin{array}{c}-0.18 \\
5\end{array}$ \\
\hline 11 & $\begin{array}{c}-0.14 \\
2\end{array}$ & 0.759 & 0.16 & $\begin{array}{c}-0.14 \\
4\end{array}$ & $\begin{array}{c}-0.19 \\
8\end{array}$ & 30 & 0.312 & 0.295 & -0.33 & 0.615 & 0.114 \\
\hline 12 & $\begin{array}{c}-0.10 \\
7\end{array}$ & $\begin{array}{c}-0.19 \\
6\end{array}$ & 0.118 & 0.402 & 0.099 & 31 & 0.486 & 0.084 & 0.523 & $\begin{array}{c}-0.26 \\
4\end{array}$ & 0.046 \\
\hline 13 & 0.245 & 0.260 & 0.564 & 0.092 & 0.037 & 32 & 0.099 & $\begin{array}{c}-0.14 \\
4\end{array}$ & 0.196 & 0.171 & 0.730 \\
\hline 14 & 0.798 & 0.12 & $\begin{array}{c}-0.01 \\
7\end{array}$ & $\begin{array}{c}-0.00 \\
1\end{array}$ & 0.68 & 33 & $\begin{array}{c}-0.04 \\
9\end{array}$ & 0.118 & -0.07 & $\begin{array}{c}-0.12 \\
7\end{array}$ & 0.723 \\
\hline 15 & $\begin{array}{c}-0.10 \\
2\end{array}$ & $\begin{array}{c}-0.19 \\
6\end{array}$ & 0.127 & 0.698 & 0.458 & 34 & 0.037 & 0.519 & 0.395 & $\begin{array}{c}-0.06 \\
3\end{array}$ & 0.169 \\
\hline 16 & 0.687 & 0.048 & -0.07 & 0.205 & 0.162 & 35 & 0.141 & $\begin{array}{c}-0.12 \\
4\end{array}$ & 0.733 & 0.129 & $\begin{array}{c}-0.32 \\
4\end{array}$ \\
\hline 17 & 0.468 & 0.084 & 0.526 & $\begin{array}{c}-0.26 \\
6\end{array}$ & 0.048 & 36 & -0.03 & 0.483 & 0.099 & 0.428 & $\begin{array}{c}-0.20 \\
5\end{array}$ \\
\hline 18 & 0.492 & 0.198 & 0.079 & $\begin{array}{c}-0.08 \\
5\end{array}$ & $\begin{array}{c}-0.43 \\
3\end{array}$ & 37 & 0.397 & 0.046 & $\begin{array}{c}-0.05 \\
9\end{array}$ & 0.245 & 0.454 \\
\hline 19 & $\begin{array}{c}-0.22 \\
3 \\
\end{array}$ & 0.081 & 0.595 & 0.156 & $\begin{array}{c}-0.08 \\
6\end{array}$ & & & & & & \\
\hline
\end{tabular}

We can see that 9, 14, 21 variables have great influence in the first principal component, the coefficients were: $0.865,0.813,0.798$. This mainly means that the lack of residential construction equipment, residential building structure and the foundation of the foundation has flaws, part of the durability of the product components, we can be summarized as: residential equipment parts system.

$7,11,23$ variables have great influence in the second principal component, the coefficients were: $0.794,0.759,0.743$. This mainly means that the lack of functional design, the space layout of the house and planning conditions has flaws, we can be summarized as: residential design system.

4, 35 variables have great influence in the third principal component, the coefficients were: $0.743,0.733$. This mainly means that government said the dismantling of "construction", moved to engage in different stages of the construction without interlocking, we can be summarized as: Residential production organization system。

22, 30 variables have great influence in the forth principal component, the coefficients were: $0.621,0.615$. This mainly means that residential land is limited, the impact of rapid population growth, we can be summarized as: residential market environment system. 
32, 33 variables have great influence in the forth principal component, the coefficients were: $0.730,0.723$. This mainly means that the life cycle cost of the housing itself and the land value is too high, we can be summarized as: the economic cost of housing system.

\section{Conclusions and recommendations}

From the previous analysis, we can see that the average service life of city residential building in China is relatively short. The influencing factors of the average service life of urban housing are complex and diverse. We analyze the influence factors of the average life of the average using the empirical research method and the following suggestions are put forward: (1) improve the administrative regulations, the rational urban planning and government decision-making, to accept social supervision; (2) to update the original technical equipment, to carry out technical training for the relevant personnel of the housing, and form the technical structure and organization structure; (3) the establishment of residential system and the Ministry of goods, the modular coordination system, to speed up the establishment of residential standards system, so that the average service life of urban residential life as far as possible[8].

\section{Reference}

[1] Tongyue zhong. Extending the length of residence using the market economy [J]. China real estate, 2005 (1): 36-39.

[2] http://xiaoning.nju.edu.cn/sciencework/2/2_3_3_2_1.html.

[3] Diane Kholos Wysoki. Readings in Social Research Methods. 2nd edition. Beijing: Peking University Press, 2004:132-145.

[4] F. H. Mustapha, S Naoum. Factors influencing the effectiveness of construction site managers. International Journal of Project Management,1998(2):1-8.

[5] Chen Shun. Research on Key Techniques of questionnaire survey in distance education evaluation [D]. Xi'an Electronic and Science University. 2006. 1.

[6] Qin Wei .Wu Jun. Social science research method [M]. Sichuan people's Publishing House. 2000:197-200.

[7] Shen Jinzhen. 2008. The phenomenon of short lived building should be strengthened from the aspects of strengthening the management of urban development [J]. Urban management frontier, (1): $36-39$.

[8] Chen Jian. 2007. Study on the life of the building under Sustainable Development [D].Tian Jin: Tianjin University. 